УДК 902/904

https://doi.org/10.24852/2587-6112.2021.2.191.206

\title{
БИКТИМИРОВСКИЙ II МОГИЛЬНИК
}

\author{
(C) 2021 г. В.В. Овсянников
}

Биктимировский II могильник является частью Биктимировского археологического комплекса, который включает в себя городище и три могильника. Комплекс представляет собой остатки родоплеменного центра кара-абызской культуры эпохи раннего железа. Биктимировские памятники неоднократно исследовались: в 1962-1964 гг. А.Х. Пшеничнюком, в 2004-2005 гг. И.М. Акбулатовым и в 2010-2011 гг. - автором статьи. Частично опубликованы лишь результаты раскопок Биктимировского I могильника и Биктимировского городища. В настоящей статье вводится в научный оборот материалы исследований Биктимировского II могильника за 1958, 1962 и 2010 гг. Приводится описание погребального обряда и инвентаря десяти погребений. Данный некрополь оставлен небольшой семейнородовой группой. Хронологические рамки существования могильника определяются в пределах IV в. до н.э. - I в. н.э. Могильник синхронен остальным древним кладбищам, входящим в Биктимировский археологический комплекс. В статье обращается внимание на то, что основная часть погребений комплекса относится к периоду III-II вв. до н.э. Таким образом, Биктимировский археологический комплекс в основном может быть отнесен к ранним этапам кара-абызской культуры. Верхняя граница функционирования комплекса в целом может быть отнесена к рубежу эр.

Ключевые слова: археология, Предуралье, ранний железный век, кара-абызская культура, грунтовый могильник, погребальный обряд, хронология.

\section{BIKTIMIROVO II BURIAL GROUND}

\section{V. Ovsyannikov}

Biktimirovo II burial ground is part of Biktimirovo archaeological complex, which includes a hillfort and three burial grounds. The complex represents the remains of a tribal center of the Kara-Abyz culture of the Early Iron Age. Biktimirovo sites have been repeatedly studied: in 1962-1964 by O.Kh. Pshenichnyuk, in 2004-2005 by I.M. Akbulatov, and in 2010-2011 - by the author of the paper. Only the results of excavations at the Biktimirovo I burial ground and Biktimirovo hillfort have been partially published. This paper introduces into scientific circulation the study materials of Biktimirovo II burial ground for 1958, 1962 and 2010. A description of the burial rite and the inventory of ten burials are provided. This necropolis was left by a small family-clan group. The chronological framework for the operation of the burial ground has been determined as the $4^{\text {th }}$ century $\mathrm{BC}-1$ st century AD. The burial ground is synchronous with the rest of the ancient cemeteries within the Biktimirovo archaeological complex. The author draws attention to the fact that the main part of the burials of the complex belongs to the period of the $3^{\text {rd }}-2^{\text {nd }}$ centuries BC. Thus, the Biktimirovo archaeological complex can be mainly attributed to the early stages of the Kara-Abyz culture. The upper limit of the operation of the complex as a whole can be attributed to the turn of the eras.

Keywords: archaeology, Pre-Urals, Early Iron Age, Kara-Abyz culture, subsoil burial ground, burial rite, chronology.

Биктимировский

археологический комплекс расположен на правом берегу $\mathrm{p}$. Белой в ее среднем течении на территории Бирского района Башкортостана возле деревни Новобиктимирово. В него входит Биктимировское городище и три могильника. Все памятники относятся к кара-абызской культуре. Наиболее раннее упоминание о Биктимировском городище опубликовано в 1883 г. в сообщении Р.Г. Игнатьева (Игнатьев, 1883, c. 344). Здесь приведена краткая информация о местонахождении памятника и указаны размеры внешнего вала. Далее памятники попали в поле зрение А.П. Шокурова. В 1955 и 1958 гг. исследователь описал городище, определив его как селище, и собрал небольшую коллекцию керамики кара-абызского типа (Шокуров, 1955). В 1955 году им было описано разрушенное погребение в окрестностях городища. Впоследствии здесь был выявлен Биктимировский I могильник, расположенный к северо-западу от городища. В 1958 году им был обнаружен Биктимировский II могильник, расположенный с противоположной юго-восточной стороны городища (Шокуров, 1958, с. 3-7).

С 1962 года начинаются планомерные исследования археологического комплекса. В этом году К.В. Сальниковым и А.Х. Пшеничнюком были заложены четыре раско- 


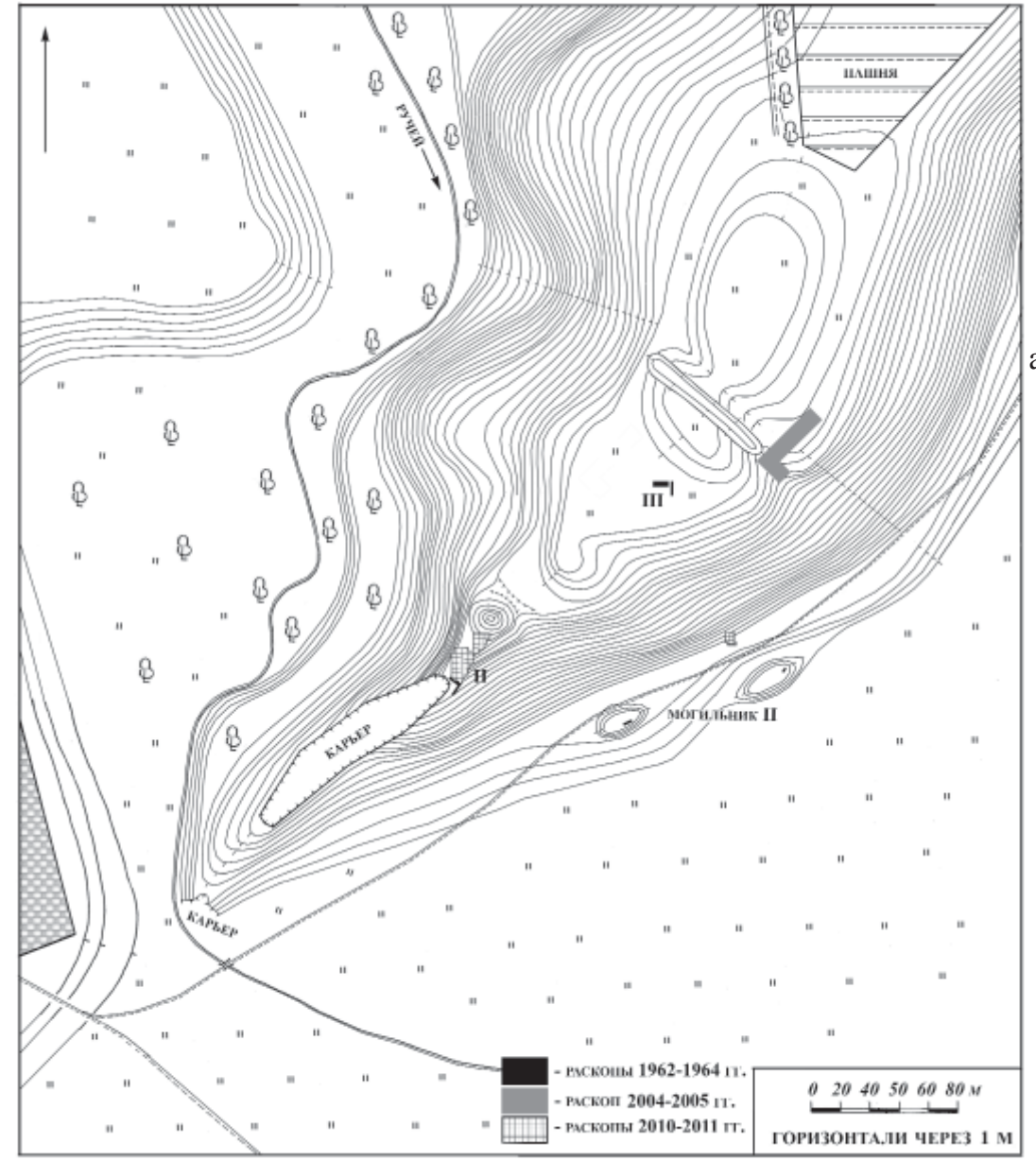

Рис. 1. Биктимировский археологический комплекс. План 2011 г.

Fig. 1. Biktimirovo archaeological complex. Plan of 2011

па на площадке городища и два раскопа на могильнике I, где было обнаружено разрушенное погребение А.П. Шокуровым (Сальников, 1962, с. 27-43). Всего было исследовано 17 погребений. Также было заложено два раскопа на II-м могильнике, где вскрыто 2 погребения (Сальников, 1962, с. 43-44). В дальнейшем исследования были продолжены А.Х. Пшеничнюком. В 1963 году им были расширены раскопы 1962 г. на могильнике I. Число исследованных погребений доведено до 47 (Пшеничнюк, 1963, с. 1-21). Материалы этих раскопок могильника I были опубликованы в статье А.Х. Пшеничнюка (Пшеничнюк, 1964a).

В 1964 году исследования были продолжены. На могильнике I было заложено три новых раскопа (III-V) в них исследовано еще 21 погребение (Пшеничнюк, 1964, с. 2-10). В этом же году был выявлен могильник III, находящийся на территории деревни. Здесь в двух раскопах было исследовано 17 погребений (Пшеничнюк, 1964, с. 12-18). Продолжены были раскопки и на городище. Был расширен раскоп 1962, заложенный на центральной жилой площадке городища (Пшеничнюк, 1964, с. 19-22). Результаты этих исследований частично вошли в обобщающую работу
А.Х. Пшеничнюка (1973). Впоследствии материалы раскопок 1964 года на городище стали предметом статьи Н.С. Савельева (2011).

Далее исследования памятника возобновились только в 2004-2005 гг. В этот период А.М. Акбулатовым был заложен раскоп у юговосточной оконечности напольного вала городища (рис. 1). В 2010-2011 гг. автором статьи исследовалась мысовая площадка городища. Во время работы экспедиции в 2010 г. у юго-восточного подножия городищенского мыса были обнаружены остатки разрушенных погребений: фрагменты костей человека и подвеска, вырубленная из бронзового зеркала (рис. 4: 1). На месте находок был заложен небольшой раскоп, где было выявлено шесть погребений. После того как был локализован раскоп 1962 года, стало ясно, что раскопом 2010 года исследована северо-западная часть могильника II (рис. 1). Основной целью данной статьи является ввод в научный оборот материалов Биктимировского II могильника за все годы его исследования.

В 1958 году А.П. Шокуровым на восточном склоне мыса, где расположено Биктимировское городище, в промоине мысовидного выступа нижней части террасы были обнаружены человеческие кости. В этом месте была 


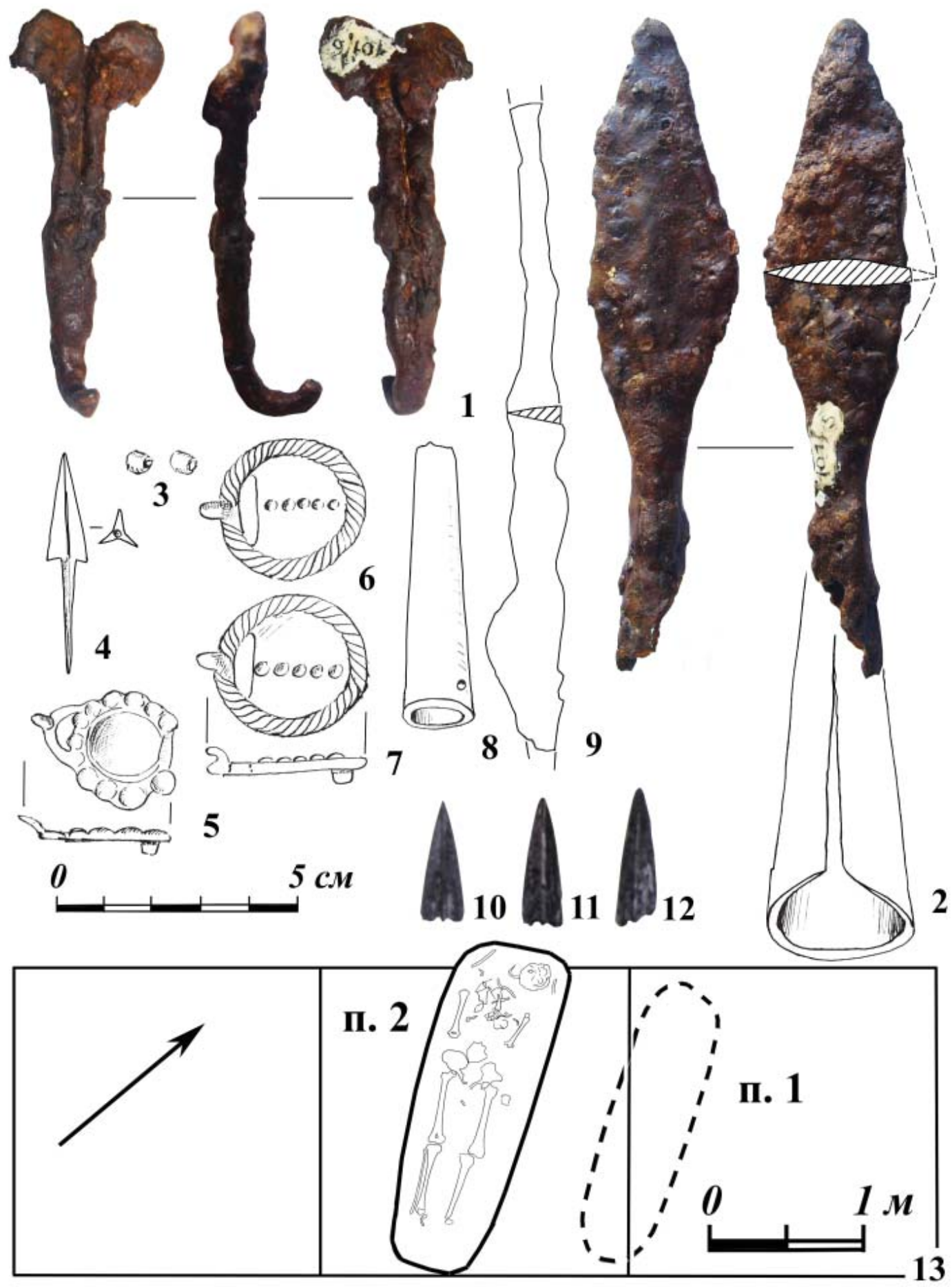

Рис. 2. Биктимировский II могильник. 1-9 - материалы раскопок А.П. Шокурова 1958 г.; 10-13 - материалы раскопок К.В. Сальникова 1962 г.

Fig. 2. Biktimirovo II burial ground. 1-9 - materials from the excavations of A.P. Shokurov 1958; 10-13 - materials from the excavations by K.V. Salnikov 1962

сделана небольшая врезка, где расчищено два погребения.

Погребение 1 (1958) было значительно разрушено размывом. Сохранившаяся часть могильной ямы имела округлую форму, глубину 1,1 м и ширину 0,95 м. Судя по остаткам костяка, погребенный был положен на спину, головой на юго-запад. У левого колена был обнаружен железный колчанный крючок (рис. 2: 1), ниже колена - железный наконеч- ник копья (рис. 2: 2). В заполнении могильной ямы найдены зуб лошади и два фрагмента керамики кара-абызского типа (Шокуров, 1958 , c. 3-4).

Погребение 2 (1958) также было частично нарушено. Судя по сохранившим свое положение костям, погребенный был уложен на спину в вытянутом положении, головой на юго-запад. У левого бедра погребенного расчищено 18 железных наконечников 


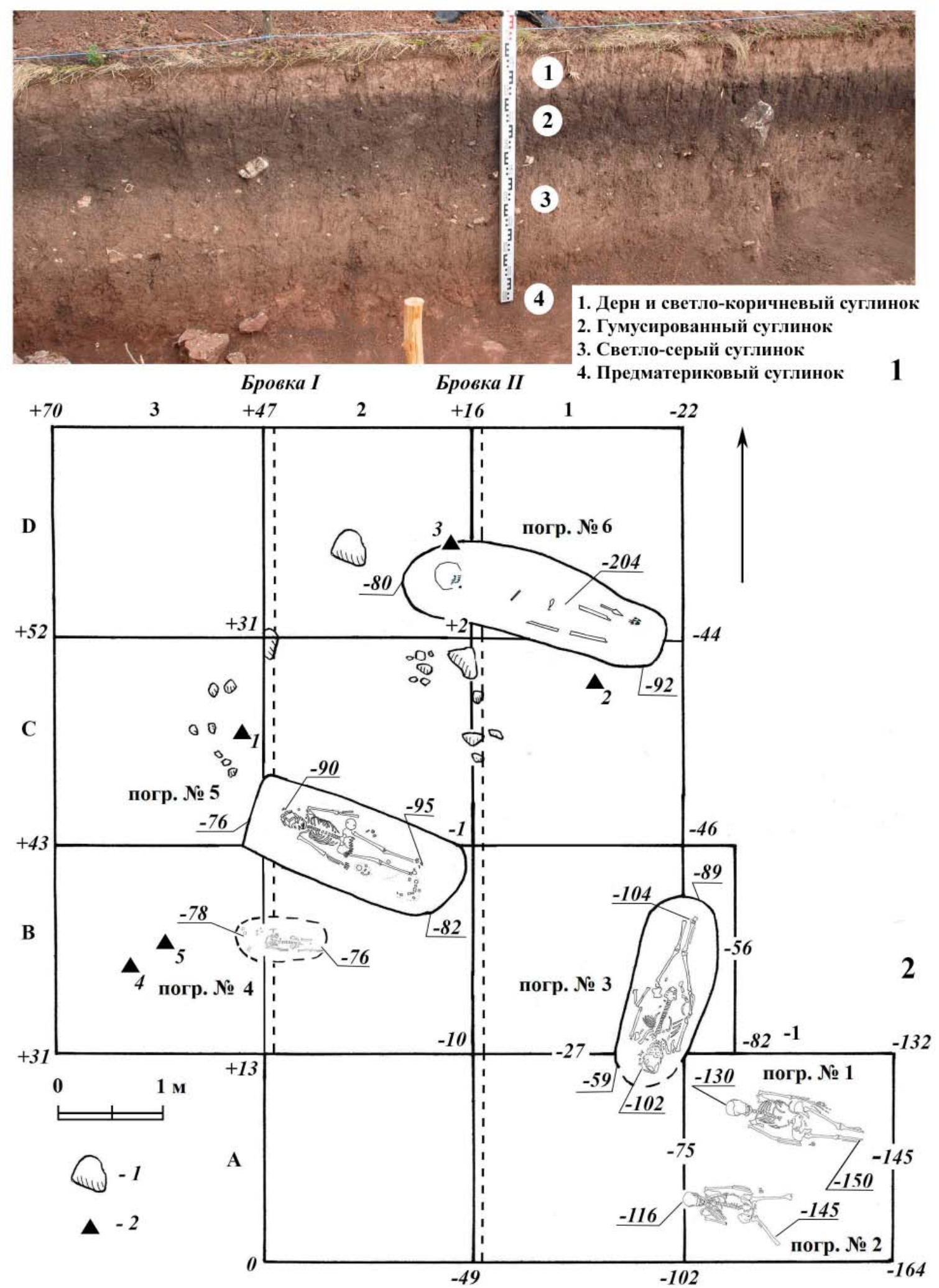

Рис. 3. Биктимировский II могильник. Материалы 2010 г. 1 - фото профиля западной стенки раскопа; 2 - план раскопа 2010 г. (1- камни; 2 - находки вне погребений)

Fig. 3. Biktimirovo II burial ground. Materials 2010. 1 - profile photo of the western wall of the excavation; 2 - excavation plan 2010 ( 1 - stones; 2 - finds outside the burials)

стрел (рис. 2: 4). Рядом с колчанным набором - костяная трубочка (рис. 2: 8). В области таза, на поясничных позвонках, была найдена бронзовая эполетовидная пряжка с неподвижным крючком и две бронзовые пронизки (рис. 2: 3,5). Справа от тазовых костей найден железный нож (рис. 2: 9). В нижней части костей ног - две круглые бронзовые пряжки с неподвижным крючком, вероятно, застежки от обуви (рис. 2: 6-7) (Шокуров, 1958, с. 4). 
Рядом с местом врезки А.П. Шокуровым были прослежены остатки еще двух погребений, от которых остались фрагменты берцовой кости и двух несохранившихся железных копий (Шокуров, 1958, с. 4-5).

Часть коллекции, полученной на памятнике в 1958 г., сохранилась в фондах Октябрьского краеведческого музея (г. Октябрьский, Башкортостан). Это железные колчанный крючок и наконечник копья (рис. 2: 1-2), остальной инвентарь известен по рисункам из отчета А.П. Шокурова (рис. 2: 3-9) (Шокуров, 1958 , с. 6-7). Место зачистки в настоящее время локализовать сложно.

В 1962 году исследование памятника было продолжено К.В. Сальниковым и А.Х. Пшеничнюком. Размыв нижней части юговосточной стороны мыса городища продолжался. По сообщениям местных жителей здесь нередко встречались человеческие кости. Было решено заложить две разведочные траншеи на возвышенных участках нижней части коренной террасы (рис. 1). В западной траншее находки отсутствовали, в восточной - выявлены два погребения. Восточная траншея имела размеры $6 \times 2$ м и была вытянута по линии юго-запад - северо-восток. Она была расположена на северо-восточной оконечности небольшой возвышенности-останца у подножия городищенского мыса (рис. 1).

Погребение 1 (1962) выявлено на глубине 0,5 м от современной поверхности в слое гумуса (рис. 2). По плохо сохранившемуся костяку можно заключить, что погребенный был уложен на спину, вытянуто, головой на северо-северо-запад. Череп и некоторые кости верхней части скелета отсутствуют. Сопровождающий инвентарь отсутствует (Сальников, 1962, с. 43).

Погребение 2 (1962) совершено в могильной яме, вытянутой по линии северо-северозапад - юго-юго-восток, размером $2,1 \times 0,65$ м и глубиной 0,75 м. На дне ямы лежал костяк взрослого человека на спине, вытянуто, головой на северо-северо-запад. Верхняя часть скелета потревожена (рис. 2). Слева у тазовых костей найден фрагмент шлака, между бедренными костями - фрагмент железного ножа. У левого коленного сустава - три бронзовых наконечника стрел (рис. 2: 10-12) (Сальников, 1962, с. 43).

В 2010 году во время исследования автором статьи площадки Биктимировского городища у подножия юго-восточного склона мыса были обнаружены следы разрушенного погребения: кости человека и бронзовая подвеска, изготов- ленная из зеркала (рис. 4: 1). В этом месте был заложен разведочный раскоп площадью $24 \mathrm{~m}^{2}$, расширенный затем до $48 \mathrm{~m}^{2}$.

Раскоп был разбит на ровной поверхности, имевшей сильный уклон с северо-запада на юго-восток. Перепад высот на поверхности в пределах раскопа составлял 2,34 м. Стратиграфия раскопа следующая: под слоем дерна залегал светло-коричневый рассыпчатый суглинок мощностью от $0,2-0,25$ м в северозападной части раскопа до 0,05 м в юго-восточной (рис. 3: слой 1). Культурных остатков в этом слое не содержалось. Эта страта образовалась в процессе сползания/смыва грунта со склона мыса. Далее следовал слой темносерого (гумусированного) рассыпчатого легкого суглинка с включениями фрагментов керамики и костей животных, его мощность - в пределах 0,2-0,25 м. В пределах раскопа - залегание почти равномерное (рис. 3: слой 2). Ниже залегал светло-серый рассыпчатый средний суглинок также с культурными остатками (рис. 3: слой 3). Мощность его в пределах раскопа 0,45-0,50 м. Слой постепенно уменьшается от северо-запада к юго-востоку. Под ним фиксировался буровато-коричневый, сухой тяжелый (предматериковый) суглинок (рис. 3: слой 4). Его мощность достигала 0,1-0.15 м. Распределялся равномерно по всей площади раскопа. Далее залегал материк - рыжевато-светлый, влажный плотный тяжелый суглинок. На уровне материка перепад высот в раскопе снижается до 0,9 м.

В раскопе выявлено шесть погребений. Два погребения совершены на поверхности предматерикового суглинка (погребения 1,2$)$, одно незначительно в него углублено (погребение 4) и два прорезают предматерик и углублены в материковый слой (погребения 5 и 6). Судя по залеганию могильных выкидов, зафиксированных на профилях бровок, верхняя поверхность предматерикового суглинка является дневной поверхностью для периода совершения захоронений. Все слои, залегавшие выше предматерика, сформировались после прекращения функционирования этой части могильника. Данные страты являются следствием «сползания» грунта с культурными остатками с верхней части склона городищенского мыса.

Вне погребений найдено шесть предметов: уже упоминавшаяся подвеска из зеркала (рис. 4: 1); бронзовая обойма (рис. 4: 2); трапециевидная подвеска из кости (рис. 4: 3); два пряслица, из глины и камня (рис. 4: 4-5), и бронзовая трапециевидная подвеска. Пряслица, вероятно, происходят из культур- 

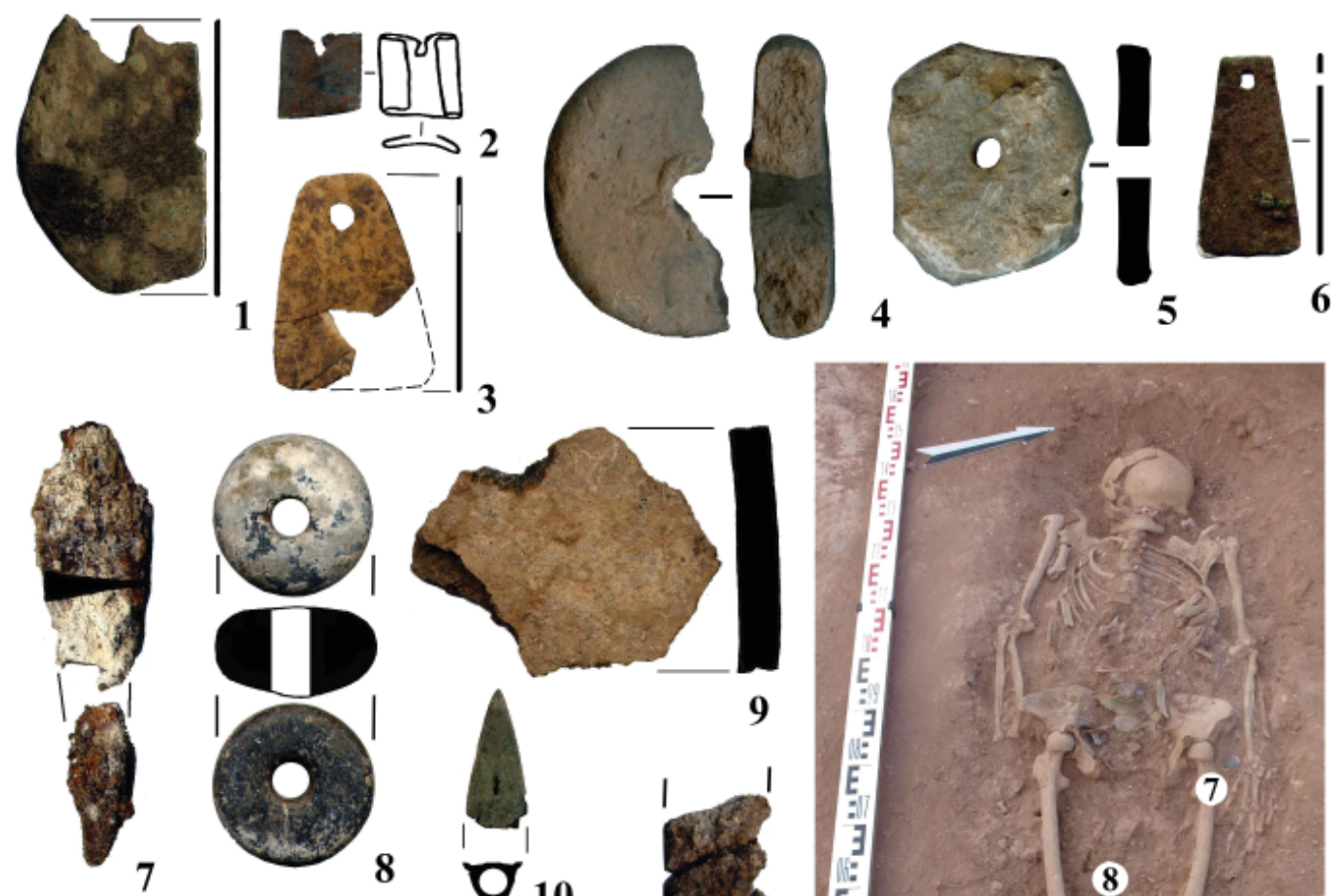

3
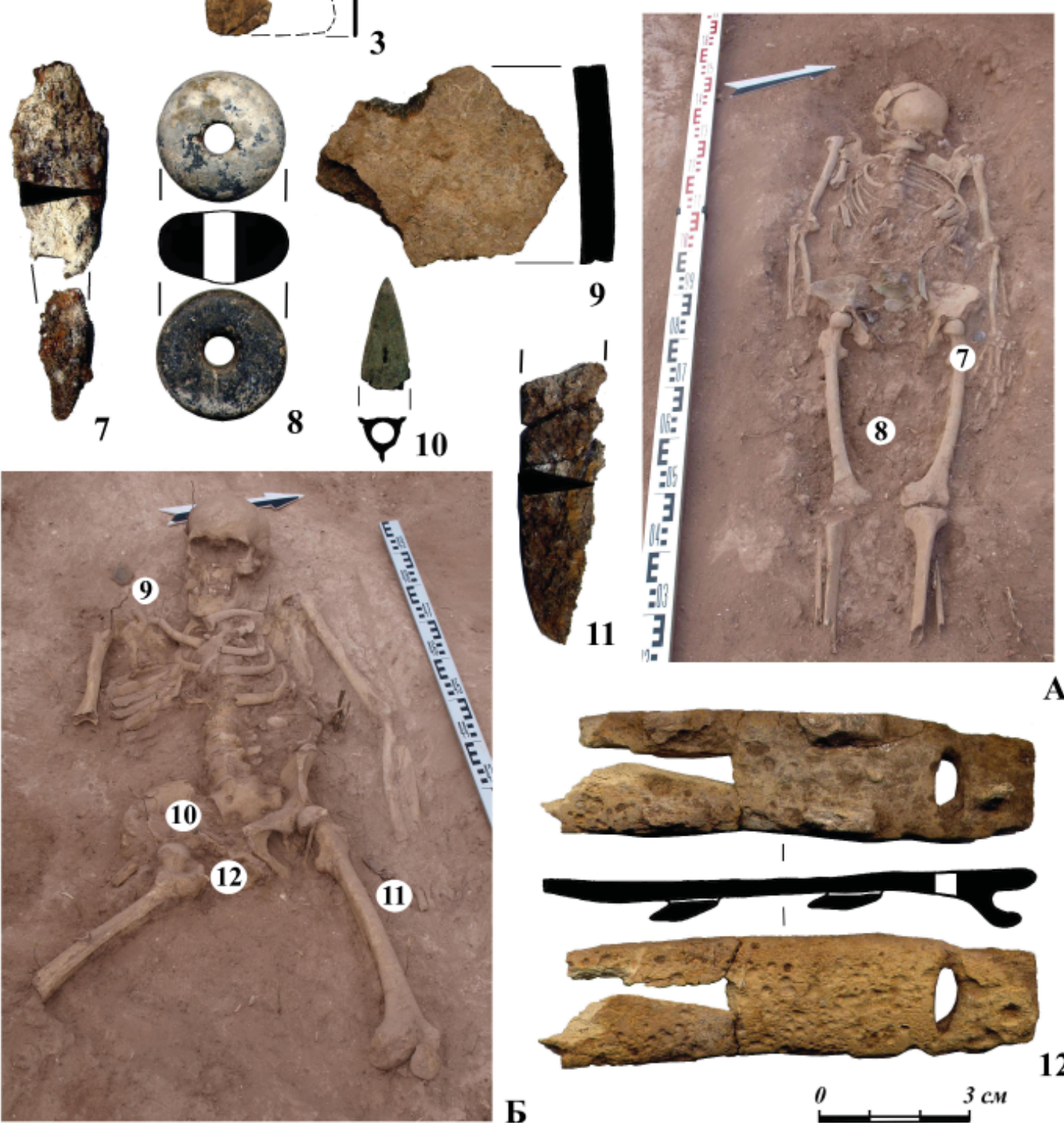

$\mathbf{A}$

Рис. 4. Биктимировский II могильник. Материалы 2010 г. 1-6 - находки вне погребений; А, 7-8 - погребение 1; Б, 9-12 - погребение 2.

Fig. 4. Biktimirovo II burial ground. Materials of 2010. 1-6 - finds outside the burials;

$$
\text { A, 7-8 - burial 1; B, 9-12 - burial } 2
$$

ного слоя городища, так же как многочисленные фрагменты керамики и костей животных. Остальные предметы могут относится к нарушенным погребениям. Вызывает интерес находка трапециевидной подвески из кости. До сих пор аналогичные предметы известны только из бронзы. Как правило, их находят в погребальных памятниках. Возможно, костяная подвеска происходит из культурного слоя поселения. Эта находка указывает на вероятность существования костяных анало- гов бронзовых украшений для повседневного костюма, в отличие от «праздничного» или «погребального», где использовались исключительно металлические украшения.

Погребение 1 (2010). Выявлено в кв. А-1 (рис. 3: 2) на глубине 0,20 м от современной поверхности в слое гумусированного суглинка. Очертания могильной ямы не фиксировались. Костяк взрослого человека удовлетворительной сохранности был уложен на спину, вытянуто, головой на запад с небольшим 
отклонением к северу. Костяк частично нарушен вмешательством землеройных животных - частично потревожены ребра и позвонки. Нижние концы берцовых костей разрушены. Кости обеих стоп отсутствовали (рис. 4: А).

Могильник был найден по остаткам данного погребения. Кости стоп частично были обнаружены в выкиде из норы животного. Там же найдена и подвеска из зеркала (рис. 4: 1). Между бедренными костями лежали обломки железного ножа (рис. 4: 7). Возле левой кисти - каменное пряслице (рис. 4: 8).

Погребение 2 (2010). Выявлено в кв. А-1 (рис. 3: 2), на глубине 0,15 м от современной поверхности к югу от погребения № 1. Погребение располагалось в слое гумусированного суглинка, могильное пятно не прослеживалось. Костяк взрослого человека удовлетворительной сохранности был уложен на спину, головой на запад. Позвоночник слегка выгнут. Костяк частично нарушен. От костей правой руки сохранилось лишь предплечье, плотно прижатое к телу. Кости левой расположены вдоль тела, несколько согнуты в локте, кисть распрямлена и вытянута вдоль бедренной кости. От ног сохранились лишь бедренные кости, причем левая вытянута, а правая расположена под углом в $45^{\circ}$ к костяку (рис. 4: Б).

При погребенном выявлен следующий инвентарь: в изголовье, с правой стороны фрагмент керамики, попавший в комплекс, скорее всего, из культурного слоя (рис. 4: 9); на правой тазовой кости выявлен бронзовый наконечник стрелы (рис 4: 10); между эпифизом левой бедренной кости и кистью руки найдено железное изделие плохой сохранности, предположительно нож (рис. 4: 11). При разборе погребения среди костей таза найдены фрагменты костяной пряжки (рис. 4: 12).

Погребение 3 (2010). Выявлено в кв. А/В-1 (рис. 3: 2). Очертания могильного пятна зафиксированы на глубине 0,3 м от современной поверхности в слое предматерикового суглинка. Заполнение ямы - гумусированный

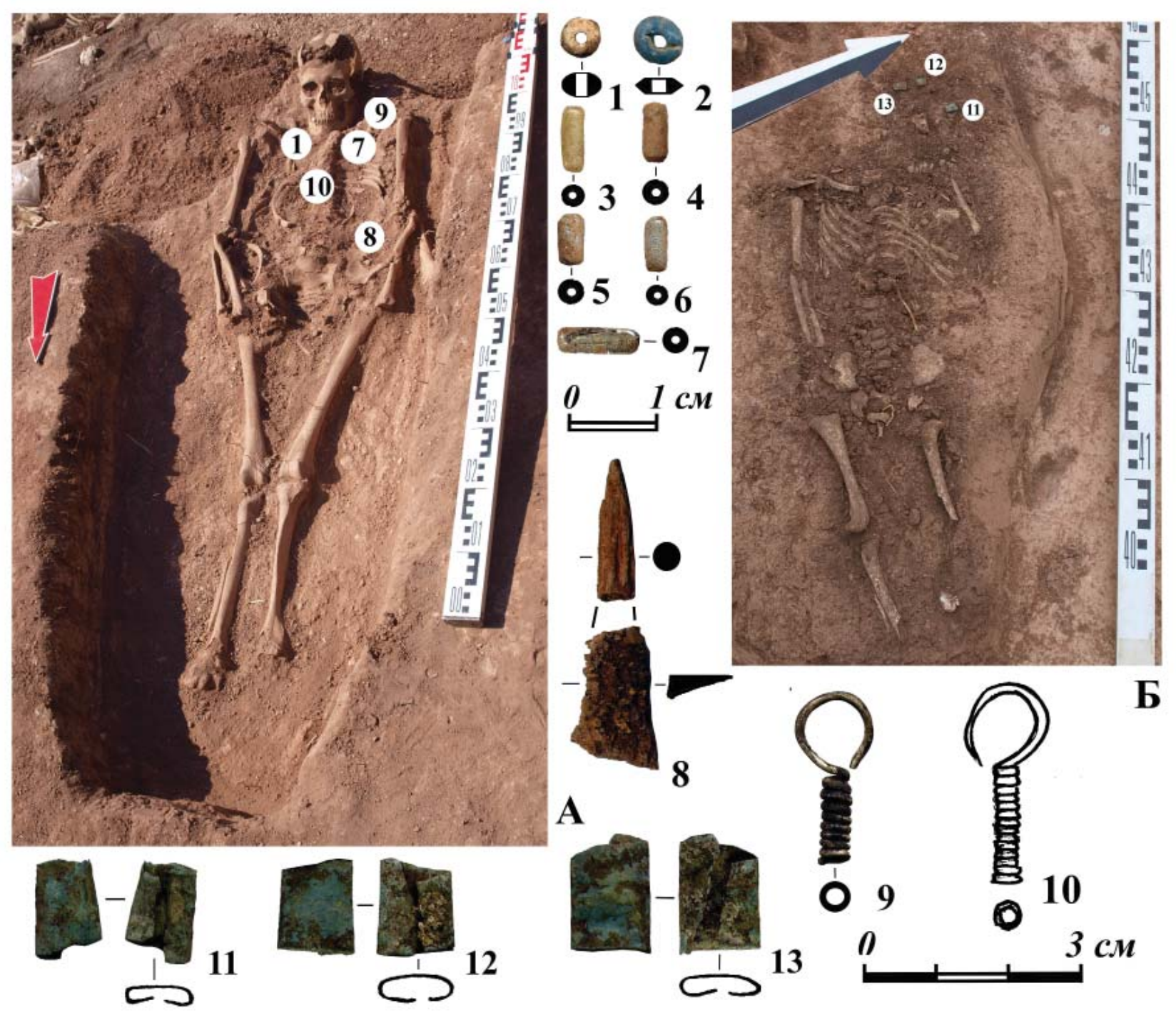

Рис. 5. Биктимировский II могильник. Материалы 2010 г. А, 1-10 - погребение 3; Б, 11-13 - погребение 4 Fig. 5. Biktimirovo II burial ground. Materials of 2010. A, 1-10 - burial 3; B, 11-13 - burial 4 
суглинок. Яма имела подовальную форму. Длинными стенками вытянута по линии север-юг с небольшим отклонением. Южная часть ямы не прослеживалась. Стенки ямы отвесные, дно ровное. Размеры: сохранившаяся длина 1,7 м при ширине в центральной части 0,8 м. Глубина ямы от уровня материка - 0,15 м. На дне ямы лежал костяк взрослого человека удовлетворительной сохранности. Умерший был уложен на спину с вытянутыми конечностями, головой на юг. Кости грудной клетки частично потревожены. Отсутствуют кости обеих кистей и стоп. Остальные кости скелета в положении in situ.

При погребенном выявлен следующий инвентарь: слева от черепа - серебряная височная подвеска (рис. 5: 9); в области шеи и верхней части груди восемь бусин из стеклянной пасты: две белых круглых непрозрачных, овальных в профиле, размер 4,6×3,4 мм (рис. 5: 1); одна голубая непрозрачная круглая с ребристым профилем, размер 5,6×2,1 мм (рис. 5: 2); три цилиндрических непрозрачных светлых оттенков, размер 6,8×2,9 мм (рис. 5: 4-6); две длинных цилиндрических непрозрачных с металлическим оттенком, размер 9,3-2,9 мм (рис. 5: 3, 7). Чуть ниже ожерелья из бус - вторая серебряная височная подвеска (рис. 5: 10). В области пояса - обломки железного ножа (рис. 5: 8). Снаружи левого предплечья - трубчатая кость животного.

Погребение 4 (2010). Выявлено в кв. В2/3 на глубине 0,96 м от современной поверхности (рис. 3: 2). Очертания могильной ямы не прослеживались, погребение совершено в слое светло-серого суглинка. Костяк ребенка удовлетворительной сохранности был уложен на спину с вытянутыми конечностями, головой на запад. Костяк частично потревожен: кости черепа были смещены и разбросаны к западу от погребения; кости левого предплечья и голени отсутствовали (рис. 5: Б). Слева от области головы найдены три бронзовые обоймы (рис. 5: 11-13).

Погребение 5 (2010). Выявлено в кв. В/ C2 (рис. 3: 2). Очертания могильной ямы выявлены на глубине 0,98 м от современной поверхности. Яма имела подпрямоугольную форму. Длинными стенками была вытянута по линии северо-запад-запад - юго-востоквосток. Размеры ямы: 2,05×0,85 м. Глубина от уровня материка - 0,15 м. Яма прорезала слой предматерикового суглинка и была углублена в материк. Могильный выкид фиксировался к северу и югу от могилы. Выкид покоился на предматериковом слое. Основное заполнение могилы - светло-серый суглинок. Вдоль краев могильной ямы, в виде своеобразной рамки, фиксировался слой, насыщенный органикой и фрагментами угольков (рис. 6: А). Толщина слоя - 0,10-0,15 м и ширина 0,15-0,25 м. Вероятно, это остатки деревянной погребальной конструкции в виде рамы из деревянных плах, частично обожженной при погребении. Стенки могильной ямы отвесные, дно ровное. На дне ямы лежал непотревоженный костяк взрослого человека. Погребенный был уложен на спину с вытянутыми конечностями, головой на северо-запад-запад (рис. 6: Б).

При погребенном выявлен следующий инвентарь: в 0,2 м к западу от черепа золотая височная подвеска (рис. 6: 21) и треугольная нашивка со спиральным орнаментом (рис. 6: 18). Справа от черепа - две бронзовые трапециевидные подвески (рис. 6: 19-20), бронзовая обойма-трубица и скопление мелких узких бронзовых обоймочек шириной $1,2 \mathrm{~cm}$ (не менее 40 экземпляров) и шириной $0,7 \mathrm{~cm}$ (не менее 40 экземпляров). Слева от черепа - бронзовая обоймочка размером 1,0-0,6 см; бронзовая конусовидная нашивка (рис. 6: 24) и бронзовая спиралевидная ажурная нашивка (рис. 6: 23). Под нижней челюстью - вторая золотая височная подвеска и 19 бусин из стеклянной пасты: одна крупная белая непрозрачная ромбовидной формы (рис. 6: 9); одна светло-серая непрозрачная круглая с овальным профилем (рис. 6: 5); одна светло-серая непрозрачная круглая с ребристым профилем (рис. 6: 4); пять белых непрозрачных круглых с овальным профилем (рис. 6: 3,6-7); одна синяя круглая непрозрачная с овальным профилем; восемь мелких светло-серых круглых с овальным профилем (рис. 6: 10-17); две цилиндрических с внутренней позолотой (рис. 6: 1-2). Под левым локтем - бронзовый перстень (рис. 6: 25).

На поясе (рис. 6: В) - бронзовая бляха, сделанная из зеркала (рис. 7: 1), коррозированный железный крючок и десять зооморфных поясных накладок с двумя ушками на обороте (рис. 7: 2-11). Снаружи правого бедра - скопление бронзовых украшений: круглая бронзовая бляха с отверстием в центре и ушком на обороте (рис. 7: 14) и две бронзовые гладкие обоймы (рис. 7: 16-17). У правого коленного сустава - бронзовая умбоновидная бляшка (рис. 7: 15).

В ногах, справа от костяка - глиняное пряслице (рис. 6: 26) и скопление бронзовых украшений (рис. 6: Г): две бронзовые круглые бляшки с ушками на обороте (рис. 7: 12-13), 

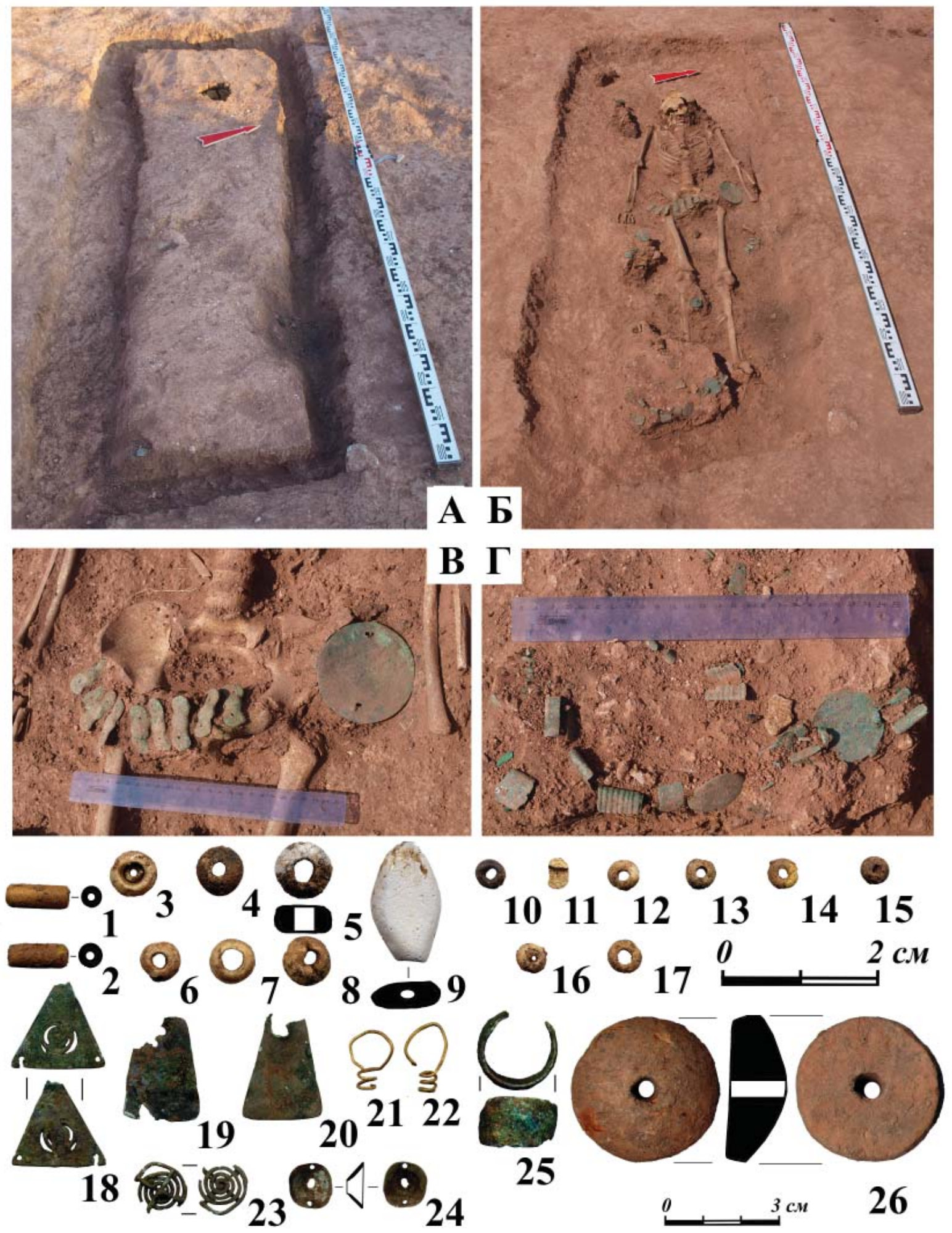

Рис. 6. Биктимировский II могильник. Материалы погребения 5 (2010 г.). А - могильное пятно; Б - погребение; В - поясной набор; Г - комплекс украшений у ног погребенного

Fig. 6. Biktimirovo II burial ground. Burial materials 5 (2010). A - grave spot; B - burial; B - belt set; $\mathrm{G}-\mathrm{a}$ set of jewelry at the feet of the buried

шесть бронзовых гофрированных обойм (рис. форму. Длинными стенками ориентирована 7: 19-20, 22-23) и девять бронзовых гладких обойм (рис. 7: 18, 21).

Погребение 6(2010). Выявлено в кв. C/D1-2 (рис. 3). Очертания могильной ямы фиксировались на глубине 0,82 м от современной поверхности. Яма имела овально-вытянутую по линии северо-запад-запад - юго-востоквосток. Размеры ямы 2,7×0,95. Стенки отвесные, дно ровное. Яма прорезала слой предматерикового суглинка и была заглублена в материк на 1,2 м. Могильный выкид, судя по профилю бровки II, лежал на предматерике. 

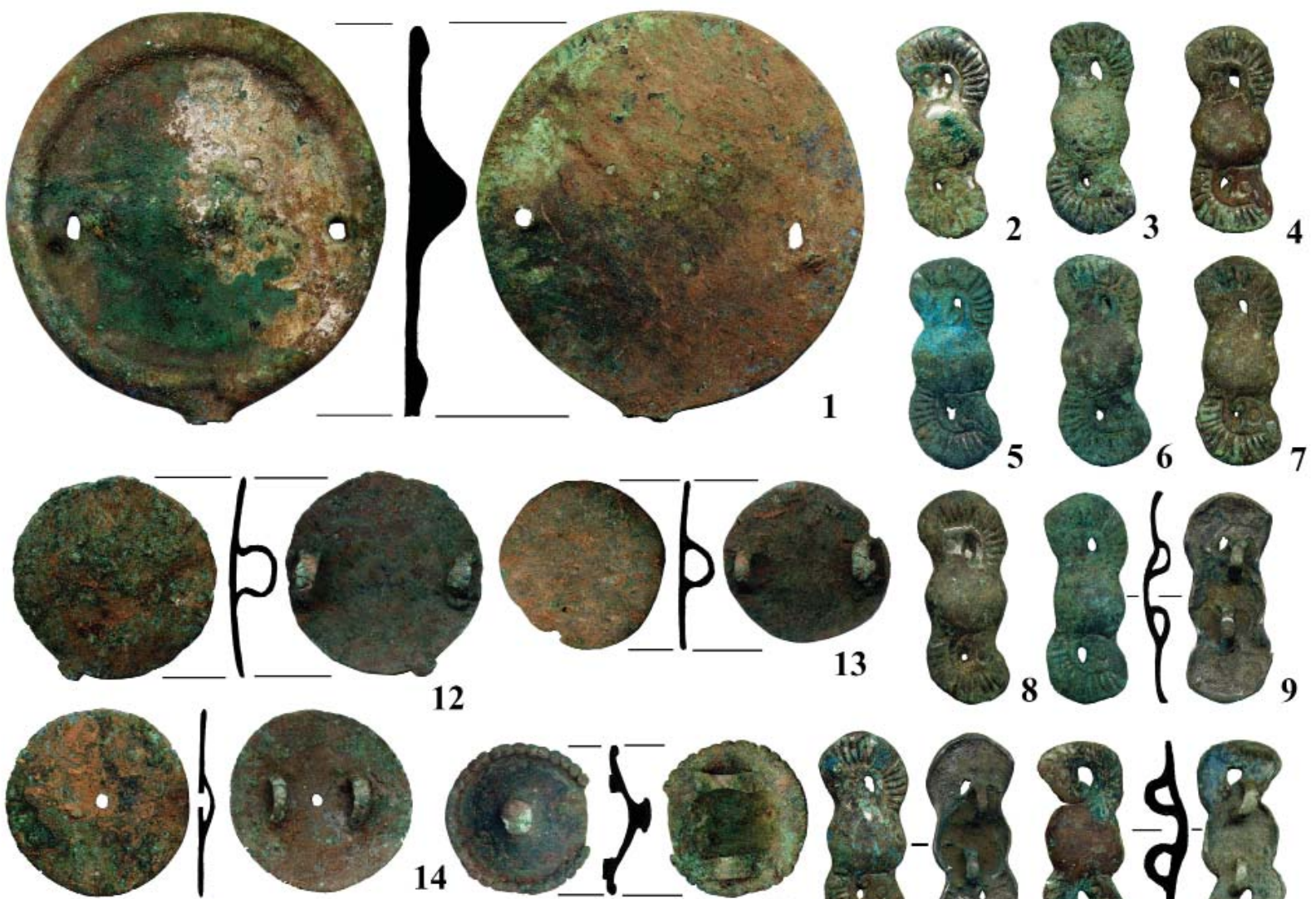

12

13
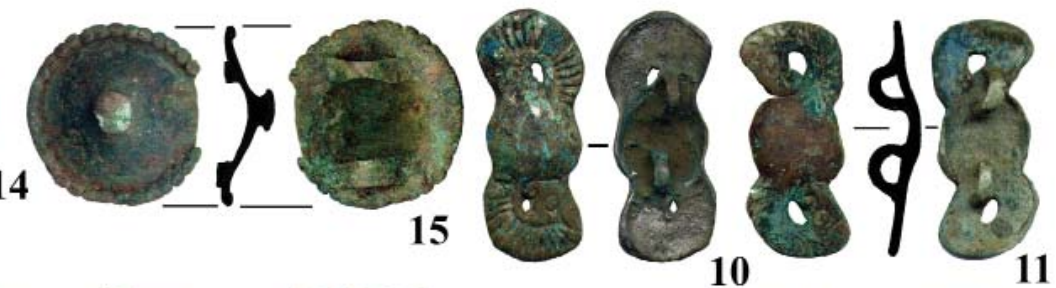
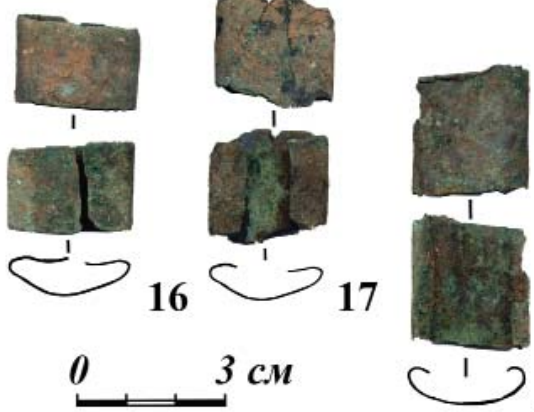

18
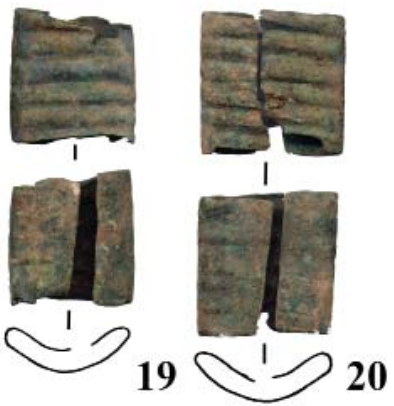
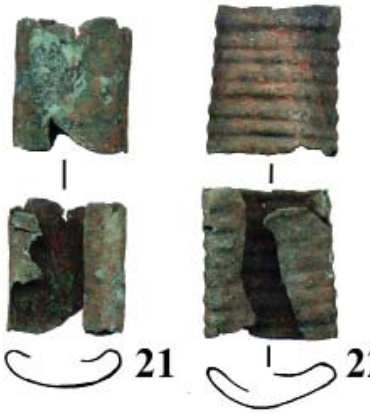

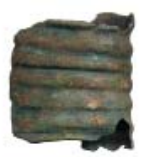

|

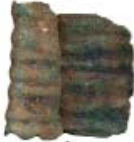

$22 \sim 1,23$

Рис. 7. Биктимировский II могильник. Материалы погребения 5 (2010 г.)

Fig. 7. Biktimirovo II burial ground. Burial materials 5 (2010)

На дне ямы - остатки плохо сохранившегося костяка взрослого человека (рис. 8). Умерший был уложен на спину, с вытянутыми конечностями, головой на северо-запад-запад.

При погребенном выявлен следующий инвентарь: справа от остатков нижней челюсти - круглая височная подвеска в полтора оборота, изготовленная из бронзовой проволоки и обернутая золотой фольгой (рис. 8: 2). Выше области пояса - сильно коррозированный железный предмет. В центре, на поясе - бронзовый зооморфный поясной крючок (рис. 8: 1). Снаружи левой голени - железный наконечник копья (рис. 8: 4). Чуть ниже копья - колчанный набор из 23 бронзовых трехлопастных наконечников (рис. 8: 5-25).

В целом за все годы исследований получена информация по десяти погребениям. Все они совершены в индивидуальных могильных ямах простой формы, подпрямоугольных или овально-вытянутых в плане. Размеры могилы зависели от антропологических параметров погребенного. Глубина могил с мужским набором инвентаря значительно превышает могилы с женскими атрибутами $(0,75-1,2$ м первые и 0,15 вторые).

Доминирующей ориентировки погребенных на могильнике нет. Присутствует широкий диапазон от южной до северо-северо-западной. Большинство погребенных ориентировано в западный сектор (юго-запад - 2; запад - 3; северо-запад-запад - 2). Положение костяков в могилах стандартное: на спине с вытянутыми конечностями. Исключение составляет погребение 2 (2010). Здесь 
у погребенного была сильно отогнута правая нога.

Следов каких-либо погребальных конструкций в могилах не зафиксировано, за исключением захоронения 5 (2010). Здесь при зачистке могильного пятна на уровне материка выявлена «окантовка» вдоль стенок могилы в виде темного грунта, выделявшегося на фоне материка и заполнения могилы более светлых оттенков (рис. 6: А). Темный грунт был насыщен остатками органики и небольшими кусочками сгоревших деревянных плах. Вероятно, это остатки деревянной конструкции в виде рамы из деревянных плах, которая плотно прилегала к стенкам могилы. Высота этой конструкции была не выше 0,150,2 м, т. е. на глубину врезки могилы в материк. Ширина плах не превышала 0,2 м. Судя по остаткам углей, эта конструкция во время обряда погребения была частично подвержена воздействию огня. Остальная часть конструкции истлела и оставила след в виде грунта более интенсивной окраски.

Следы обожженных деревянных конструкций именно в женских погребениях зафиксированы нами в двух случаях при исследовании курганной части Шиповского могильника. Здесь в женском погребении кургана 24 группы II вдоль одной из длинных стенок могилы фиксировалась частично обожженная деревянная плаха. В другом случае в кургане 5 группы III по обеим сторонам от остатков женского костяка 4 зафиксированы следы истлевшей одной деревянной плахи и углистый след от другой - остатки деревянной погребальной рамы (Овсянников, 2018, рис. 4).

Таким образом, в материалах кара-абызской культуры на данный момент имеется три случая фиксации следующего элемента погребального обряда: устройства в могиле деревянной конструкции в виде рамы и последующее частичное воздействие огня на нее. Пока данный элемент зафиксирован только в женских погребениях.

Аналогичные конструкции хорошо известны по ананьинским древностям. А.А. Чижевским они определены как «деревянные гробницы I типа» (Чижевский, 2008, с. 29). Наиболее близок биктимировскому погребению и шиповским захоронениям вариант 1 - в виде рамы из сруба или плах, облицовывающей стенки могилы (Чижевский, 2008, рис. 15).

Состав погребального инвентаря довольно четко позволяет выделить мужские, женские и детские комплексы. Мужские, как правило, выделяются по наличию предметов вооружения (наконечники стрел и копий) и небольшому количеству деталей костюма (пряжки и застежки). Остатки колчана (бляшки, крючки и наконечники стрел) уложены слева от костяка на уровне бедра (4 случая). Наконечник копья слева у голени, острием к ногам (два случая). Застежки в районе пояса (3 случая) и в районе стоп (1 случай).

Женские - наличием пряслиц, личных и костюмных украшений. Пряслица встречены в двух случаях: между бедренными костями и снаружи правой голени. Бусы и височные подвески всегда в области шеи и головы. Наиболее богатый набор украшений встречен в погребении 5 (2010). Здесь присутствует комплекс головных украшений. Среди них кроме золотых височных подвесок (рис 6: 21-22) средней пробности 858-863 (Зайков и др., 2011, табл. I) треугольная нашивка со спиральным орнаментом (рис. 6: 18), ажурная спиральная нашивка (рис. 6: 23), конусовидная нашивка (рис. 6: 24). Все эти предметы, к сожалению, были потревожены, вероятно, землеройными животными, поэтому реконструировать расположение этих предметов на головном уборе не представляется возможным.

Справа от черепа компактно и в непотревоженном виде были зафиксированы две трапециевидные подвески (рис. 6: 19-20) вместе с пронизками-трубицами и множеством мелких обоймочек, крепившихся на кожаные ремешки. Судя по расположению, трубицы крепились непосредственно возле трапециевидных подвесок, затем ремешки украшались узкими мелкими обоймочками. Количество этих украшений (не менее 80 экземпляров) предполагает, что ремешки, которые они украшали, были довольно длинными. Данный комплекс можно предварительно отнести к накосным украшениям. Подобные украшения встречены при исследовании Биктимировского I могильника (Пшеничнюк, 1964a, рис. 4).

Справа от костяка были уложены украшения, обычно относимые к «портупейным» украшениям: круглые бляхи с ушками (рис. 7: 12-14) и крупные гладкие или гофрированные обоймы (рис. 7: 16-23). В женских кара-абызских погребениях они располагаются вытянуто в две полосы на груди, как это зафиксировано в погребении 46 Биктимировского I могильника (Пшеничнюк, 1964а, рис. 6), либо сложены возле погребенных. С.В. Воробьевой высказано предположение, что данные «портупеи» представляют собой остатки 

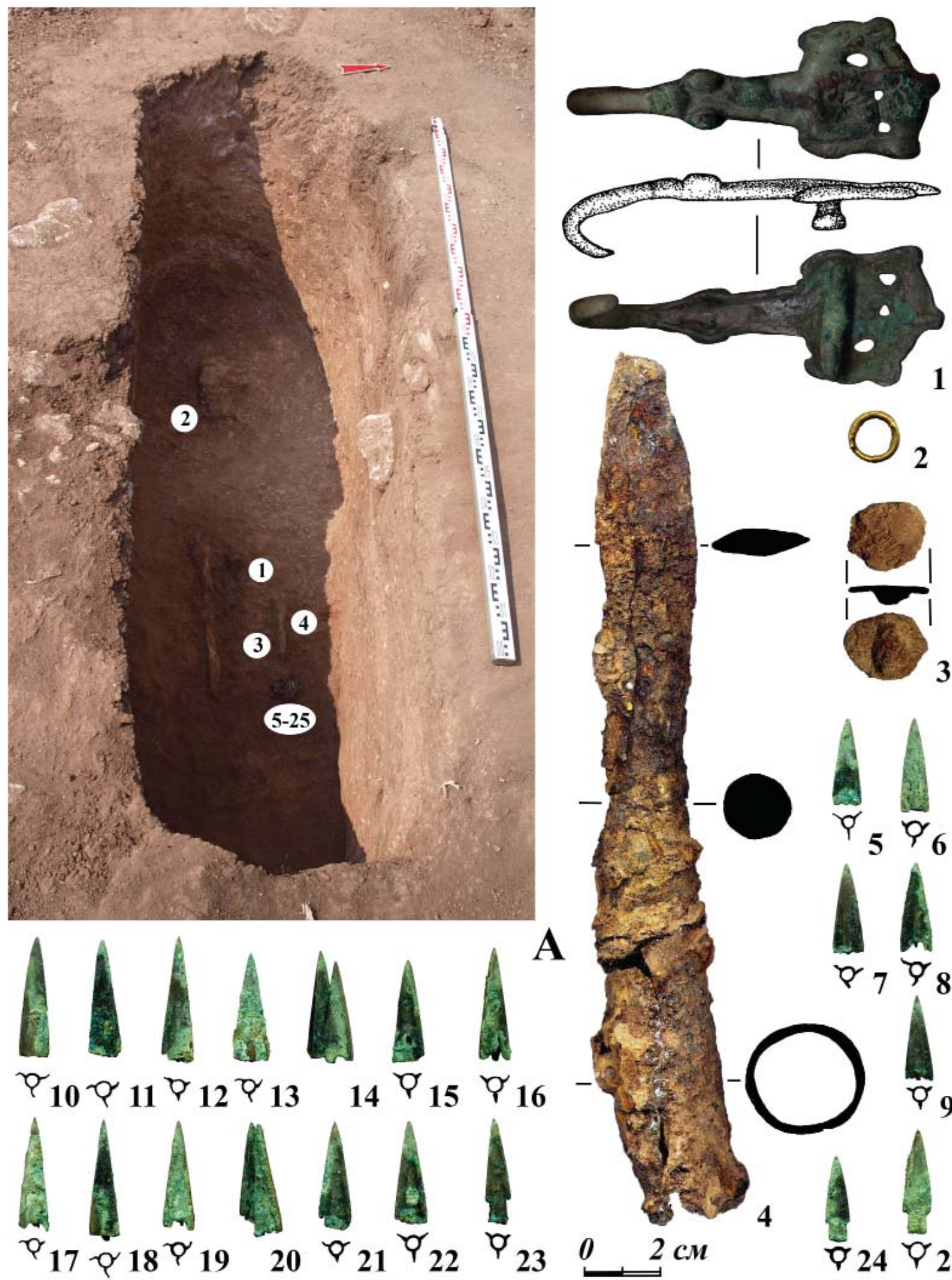

A
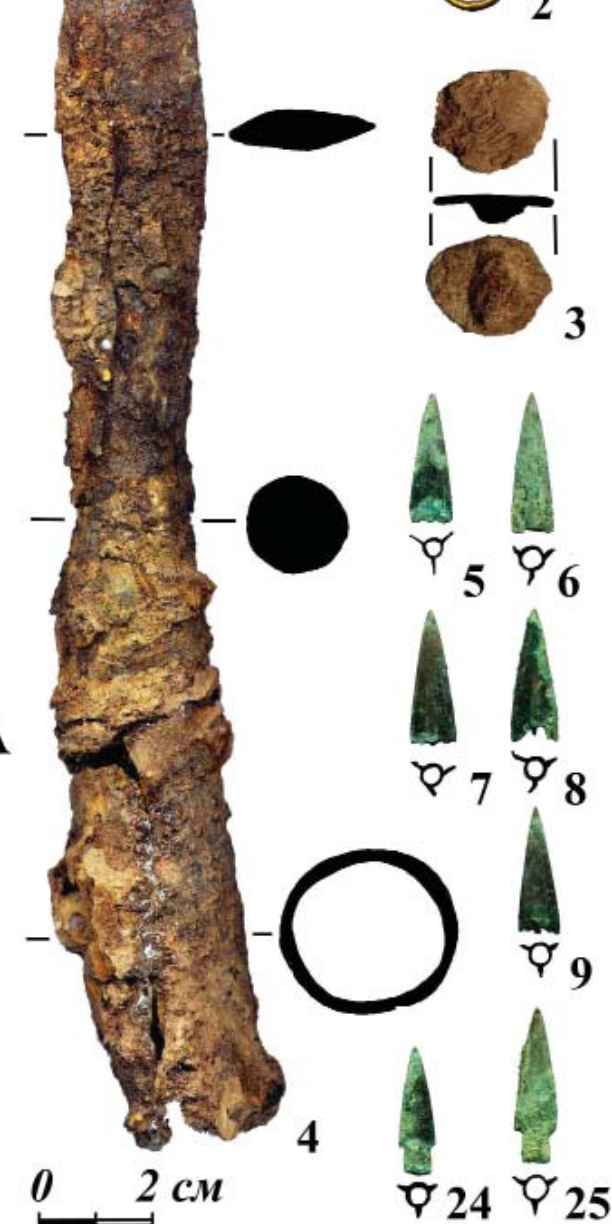

Рис. 8. Биктимировский II могильник. Материалы погребения 6 (2010 г.)

Fig. 8. Biktimirovo II burial ground. Burial materials 6 (2010)

нагрудников, аналогично тем, что хорошо известны по этнографии в женских костюмах финно-угорских и тюркских народов Поволжья (Воробьева, 2019, с. 52).

При исследовании курганной части Шиповского могильника нами было найдено женское погребение с подобными украшениями, лежавшими in situ. Благодаря почвенным условиям и обилию бронзовых украшений в этом комплексе сохранились органические детали одежды. Благодаря последним было установлено, что так называемые «портупеи» с обилием массивных бронзовых деталей крепились к верхней одежде, изготовленной из толстой прочной кожи, возможно, меховой. Из данных этнографии известно, что по представлениям финно-пермских народов в потустороннем мире царит холод и поэтому нередко покойников снабжали зимней одеждой (Шутова, 2001, с. 121). Возможно, в нашем случае возле погребенной была 
уложена теплая меховая одежда, украшенная «портупейным» набором украшений.

Богатый украшенный пояс с бляхой, изготовленной из зеркала и десяти зооморфных накладок, был уложен поверх погребенной в расстегнутом виде (рис. 5: В). Такой обряд известен и на Биктимировском I могильнике (Пшеничнюк, 1964, с. 217).

Детское погребение на Биктимировском II могильнике встречено одно и сопровождается лишь тремя бронзовыми обоймами неясного назначения.

Среди мужских погребений наиболее ранним можно считать погребение 6 (2010). Здесь встречен бронзовый зооморфный крючок, колчанный набор из 23 бронзовых наконечников стрел, височная подвеска в полтора оборота, железный наконечник копья и бляшка из кости (рис. 8: 1-25). Поясной крючок нами рассматривался в отдельной публикации (Овсянников, Тагиров, 2011, с. 50-51). Это изделие близко по оформлению застежкам среднедонского типа. Для караабызских древностей они характерны для IV-III вв. до н. э. Аналогичные изделия встречены в ранних погребениях Охлебининского могильника и курганной группы I Шиповского могильника. Наличие колчанного набора с двумя десятками бронзовых наконечников также характерно для этого периода.

Височная подвеска представляет собой бронзовое колечко в полтора оборота, обернутое золотой фольгой средней пробности 833/834 (Зайков и др., 2011, табл. I). Подобные украшения характерны для кара-абызских погребений ранней стадии IV-III вв. до н. э. В частности, они хорошо представлены в I группе курганов Шиповского могильника (Пшеничнюк, 1976, рис. 6, 1-3).

Железный наконечник копья из погребения 6 (2010) имеет листовидное (лавровидное) узкое перо. Длина пера примерно равна длине втулки. На нижней части втулки имеется железная обойма. При рассмотрении наконечников копий из курганной части Шиповского могильника подобные наконечники были выделены нами в тип I (Овсянников, 2016, c. 217). Биктимировский экземпляр наиболее близок копьям из курганной группы I Шиповского могильника, датируемой IV-III вв. до н. э. Многочисленные аналогии данному типу наконечников происходят из скифских и раннепрохоровских древностей (Овсянников, 2016). В Биктимировском археологическом комплексе похожий наконечник происходит из погребения 38 могильника I. Состав инвен- таря этого погребения практически повторяет рассматриваемый комплекс: наконечник копья, не менее 10 бронзовых наконечников стрел, золотая височная спиральная подвеска и две круглые бронзовые бляшки (Пшеничнюк, 1964a, рис. 7, 3, 8-10, 14-16, 25). A.X. Пшеничнюк отнес этот комплекс к периоду III-II вв. до н. э. (Пшеничнюк, 1973, рис. 5). Такая стандартизация набора инвентаря на протяжении длительного времени позволяет думать об устоявшейся социальной роли умерших, сопровождаемых подобным ассортиментом вещей.

К этому же времени можно отнести и погребение 2 (2010). Из него происходит один бронзовый наконечник стрелы со сводчатой головкой (рис. 4: 10). Наконечники такой формы встречаются в кара-абызских погребениях также в период IV-III вв. до н. э. Остальной инвентарь этой группы мужских погребений представлен костяными изделиями. В погребении 6 (2010) это бляшка-застежка колчана, изготовленная из черепной крышки (об этом говорят следы сагиттального шва) дикого животного, возможно, медведя. Подобных изделий пока не выявлено в кара-абызских древностях. Чаще в качестве колчанных застежек использовались бронзовые круглые бляшки с ушком на обороте, чью форму и повторяет наша костяная бляшка.

Оригинальной находкой является также костяная поясная застежка из погребения 2 (2010) (рис. 4: 12). Наиболее близкой, но далеко не полной аналогией этому изделию может служить пряжка из погребения 64 Охлебининского могильника (Пшеничнюк, 1968 , рис. 16,5$)$. Однако она происходит из комплекca c 10 железными наконечниками стрел, что позволяет его отнести к более позднему времени рубежа эр (Пшеничнюк, 1968, с. 98). Биктимировский экземпляр отличается наличием, кроме неподвижного крючка, четырьмя выступами на оборотной стороне. В целом эволюция костяных застежек в кара-абызской культуре практически не рассматривалась. Здесь можно лишь заметить, что образцы удлиненной формы, подобной биктимировскому и охлебининскому, встречаются очень редко.

В раскопе К.В. Сальникова встречено погребение с тремя бронзовыми наконечниками стрел (рис. 2: 10-12). Малое количество стрел в колчанном наборе и их форма - пирамидальные с внутренней втулкой (т. н. базисные) - говорят, что данное захоронение совершено в конце времени использова- 
ния бронзовых наконечников. Для кара-абызских древностей это период III-II вв. до н. э. (Овсянников, 2020, с. 88).

Благодаря исследованиям А.П. Шокурова сохранилась информация по двум воинским комплексам Биктимировского II могильника. Датировка погребения 2 (1958) не вызывает вопросов. Наличие колчанного набора из 18 железных наконечников стрел и пряжек с неподвижными крючками (рис. 2: 4-7) позволяет с уверенностью отнести время захоронения к рубежу эр.

Дата погребения 1 (1958) может быть определена по колчанному крючку. Он имеет характерное валютообразное завершение (рис. 2: 1). Аналогичный крючок происходит из погребения 2 раскопа I Охлебининского могильника, где он встречен совместно с железными пряжками с подвижными язычками и тремя железными наконечниками стрел (Пшеничнюк, 1968, рис. 13, 15). С таким же валютообразным завершением найден колчанный крючок в погребении 102 грунтовой части Шиповского могильника совместно с двумя железными пряжками с подвижными язычками и кольчатыми удилами (Пшеничнюк, 1976, с. 106; Пшеничнюк, 1972, рис. 62). Все упомянутые комплексы можно отнести к рубежу эр. Таким образом, воинские погребения, изученные А.П. Шокуровым, относятся ко времени І в. до н. э. - І в. н. э.

Из женских комплексов наиболее представительным является погребение 5 (2010). Здесь найдено большое количество украшений, из которых наибольшую хронологическую информацию несет поясной набор. Пояс был украшен бляхой, изготовленной из сарматского зеркала типа 6.5 (Скрипкин, 1990, с. 95). Этот тип зеркал получил распространение во II-I вв. до н. э. (Скрипкин, 1990, с. 152). Зооморфные поясные накладки с изображением голов грифонов относятся к раннему варианту этих изделий и характерны для памятников кара-абызской культуры III-II вв. до н. э. Таким образом, наиболее вероятной датой совершения захоронения 5 (2010) можно считать II в до н. э.
Ожерелья из бус, встреченные в погребениях 3 (2010) и 5 (2010), к сожалению, имеют широкий хронологический диапазон бытования и не могут служить для уточнения датировки.

Исследованная часть Биктимировского II могильника начала использоваться уже на ранней стадии существования кара-абызской культуры в IV-III вв. до н. э. К этому периоду относится воинское погребение 6 (2010) и, возможно, погребение 2 (2010). К следующему этапу (III-II вв. до н. э.) можно отнести погребения 2 (1962), 3 (2010), 5 (2010). Наиболее поздним временем (рубежом эр) датируются захоронения, исследованные А.П. Шокуровым. Общие хронологические рамки могильника, таким образом, можно определить в пределах IV в. до н. э. - I в. н. э.

На Биктимировских III и I могильниках также преобладают погребения III-II вв. до н. э. Вероятно, жизнь на Биктимировском городище наиболее интенсивно протекала именно в этот период. Погребений позднего времени (рубежа эр) на всех Биктимировских могильниках исследовано немного. Это отличает данный некрополь от Шиповского грунтового и Охлебининского могильников, где основная часть погребений относится к периоду II в. до н. э. - II вв. н. э. и более позднего II-III вв. н. э. (Пшеничнюк, 1968, с. 88-90).

Вероятно, разными хронологическими позициями объясняется и различная планиграфическая ситуация на кара-абызских могильниках. Для всех Биктимировских могильников характерно расположение могил группами без господствующей ориентировки (Пшеничнюк, 1964a, рис. 1). Между группами, как правило, имеются значительные незаполненные пространства. Рядность в погребениях практически отсутствует. Следы каких-либо ритуальных действий в межмогильном пространстве также не выявлены. Аналогичная картина фиксируется и на Уфимском могильнике, где основная часть погребений относится к IV-III вв. до н. э. (Овсянников, Яминев, 2003, рис. 11). Вероятно, такое устройство кладбищ характерно для раннего этапа существования кара-абызской культуры.

\section{ЛИТЕРАТУРА}

Воробьева С.Л. Типы костюмных комплексов носителей кара-абызской культуры эпохи раннего железа // Археология Евразийских степей. 2019. № 1. С. 50-69.

Зайков В.В., Султанова А.Н., Сиротин С.В., Овсянников В.В., Епимахов А.В., Юминов А.М. Состав древнего золота Башкортостана // УАВ. 2011. № 11. С. 53-65.

Игнатьев Р.Г. Памятники доисторических древностей Уфимской губернии, как-то: древние здания, городища, Ногайские валы, курганы, древние находки и т.д. // Справочная книжка Уфимской губернии. 
Сведения числовые и описательные относятся к 1882-83 гг. и только весьма немногие к прежним годам. / Сост. Н.А. Гуревич. Уфа: печатня Н. Блохина, 1883. С. 328-355.

Овсянников B.B. Наконечники копий из курганной части Шиповского могильника // Урал-Алтай: через века в будущее: Материалы VII Всероссийской тюркологической конференции (с международным участием), посвященной 95-летию видного ученого-тюрколога Э.Р. Тенишева. / Отв. ред. Р.Н. Сулейманова Уфа: ИИЯЛ УНЦ РАН, 2016. С. 216-220.

Овсянников В.В. Новые материалы Шиповского курганно-грунтового могильника в лесостепном Предуралье // УАВ. 2018. №. 18. С. 43-62

Овсянников В.В. Об одном типе ножен рубежа эр в Урало-Поволжье // Археология Евразийских степей. 2020. № 6. С. 87-99.

Овсянников В.В., Тагиров Ф.М. Новые находки зооморфных поясных крючков из памятников лесостепного Предуралья // УАВ. 2011. № 11 С. 50-52.

Овсянников В.В., Яминов А.Ф. Исследования могильника у Чертова городища в Уфе (1911-1912 гг.) // УАВ. 2003. № 4. С. 16-58.

Пшеничнюк A.X. Научный отчет об археологических исследованиях в центральных районах Башкирской АССР в 1963 г. / НОА ИА РАН, Ф-1. Р-1. № 2676. 39 л.

Пшеничнюк A.X. Научный отчет о результатах археологической экспедиции за 1964 г. / НОА ИА РАН. Ф-1. Р-1. № 2890. 48 л.

Пшеничнюк А.Х. Биктимировский могильник // АЭБ. Т. ІІ. Ред. Р.Г. Кузеев, К.В. Сальников Уфа: БФАН СССР, 1964a. С. 215-231.

Пшеничнюк A.X. Охлебининский могильник // АЭБ. Т. ІІІ / Отв. ред. Р.Г. Кузеев. Уфа: БФАН СССР, 1968. С. 59-104.

Пшеничнюк A.X. Отчет о работах археологического отряда ИИЯЛ БФ АН СССР в 1972 г. / НОА ИА РАН Ф-1. Р-1. № 4724.

Пиеничнюк A.X. Кара-абызская культура (население центральной Башкирии на рубеже нашей эры) // АЭБ. Т. V. / Ред. Н.В. Бикбулатов, Р.Г. Кузеев, Н.А. Мажитов. Уфа: БФАН СССР, 1973. С. $162-243$.

Пиеничнюк A.X. Шиповский комплекс памятников (IV в. до н.э. - III в. н.э.) // Древности Южного Урала / Ред. Р.Г. Кузеев, Н.А. Мажитов, А.Х. Пшеничнюк. Уфа: БФАН СССР, 1976. С. 35-131.

Сальников К.В. Отчет о результатах археологической экспедиции за 1962 г. по теме: «Эпоха железа и бронзы в Башкирии», раздел «Эпоха бронзы Южного Урала» / НОА ИА РАН Ф-1. Р-1. № 2462. 52 л.

Савельев Н.С. Гафурийский керамический комплекс Биктимировского городища в лесостепи Южного Приуралья // РА. 2011. № 2. С. 56-66.

Скрипкин A.C. Азиатская Сарматия. Проблемы хронологии и ее исторический аспект. Саратов: Изд-во Саратовского ун-та, 1990. 300 с.

Чижевский A.A. Погребальные памятники населения Волго-Камья в финале бронзового - раннем железном веках (предананьинская и ананьинская культурно-исторические области) / Археология евразийских степей. Вып. 5. Казань: Школа, 2008. 172 с.

Шокуров А.П. Отчет об археологической разведке летом 1955 г. в Кушнаренковском районе Башкирской АССР. Т. 1. / НОА ИА РАН. Ф-1. Р-1. № 1096. 129 л., 61 ил.

Шокуров А.П. Отчет об археологических работах Третьего разведывательного отряда Башкирской археологической экспедиции в 1958 г. Ч. 2. / НОА ИА РАН Ф-1. Р-1. № 1725.121 л., 87 ил.

Шутова Н.И. Дохристианские культовые памятники в удмуртской религиозной традиции: опыт комплексного исследования. Ижевск: Удмуртский институт истории, языка и литературы УрО РАН, 2001. 304 c.

\section{Информация об авторе:}

Овсянников Владимир Владиславович, кандидат исторических наук, заведующий отделом, Ордена Знак Почета Институт истории, языка и литературы УФИЦ РАН (г. Уфа, Poccия); atliural@ yandex.ru

\section{REFERENCES}

Vorobeva, S. L. 2019. In Arkheologiia Evraziiskikh stepei (Archaeology of Eurasian Steppes) 1, 50-69 (in Russian).

Zaikov, V. V., Sultanova, A. N., Sirotin, S. V., Ovsyannikov, V. V., Epimakhov, A. V., Yuminov, A. M. 2012. Ufimskii arkheologicheskii vestnik (Ufa Archaeological Herald) (22), 53-65 (in Russian).

Ignat'ev, R. G. 1883. In Spravochnaia knizhka Ufimskoi gubernii. (Reference Book of Ufa Governorate). Ufa, 328-355 (in Russian).

Ovsyanikov, V. V. 2016. In Suleimanova, R. N. (ed.). Ural-Altai: cherez veka v budushhee (Ural-Altai: Through the Centuries into the Future). Ufa: Russian Academy of Sciences, Urals Scientific Center, Institute for History, Language, and Literature, 216-220 (in Russian).

Ovsyanikov, V. V. 2018. Ufimskii arkheologicheskii vestnik (Ufa Archaeological Herald) (18), 43-62 (in Russian). 
Ovsyannikov, V. V. 2020. In Arkheologiia Evraziiskikh stepei (Archaeology of Eurasian Steppes) 6, 87-99 (in Russian).

Ovsyanikov, V. V., Tagirov, F. M. 2011. Ufimskii arkheologicheskii vestnik (Ufa Archaeological Herald) (11), 50-52 (in Russian).

Ovsyanikov, V. V., Yaminov, A. F. 2003. In Ufimskii arkheologicheskii vestnik (Ufa Archaeological Herald) (4), 16-58 (in Russian).

Pshenichniuk, A. Kh. 1963. Nauchnyi otchet ob arkheologicheskikh issledovaniiakh v tsentral'nykh raionakh Bashkirskoi ASSR v 1963 g. (Scientific Report on Archaeological Studies in the Central Districts of the Bashkir ASSR in 1963). Archive of the Institute of Archaeology of the RAS, Found-1. R-1, Inv. no 2676 (in Russian).

Pshenichniuk, A. Kh. 1964. Nauchnyi otchet o rezultatakh arkheologicheskoi ekspeditsii za 1964 g. (Scientific Report on the Results of the Archaeological Expedition in 1964). Archive of the Institute of Archaeology of the RAS, Found-1. R-1, Inv. no 2890 (in Russian).

Pshenichniuk, A. Kh. 1964a. In Kuzeev, R. G., Sal'nikov, K. V. (eds.). Arkheologiia i etnografiia Bashkirii (Archaeology and Ethnography of Bashkiria) II. Ufa: Bashkirian Branch of the USSR Academy of Sciences, 215-231 (in Russian).

Pshenichniuk, A. Kh. 1968. In Kuzeev, R. G. (ed.). Arkheologiia i etnografiia Bashkirii (Archaeology and Ethnography of Bashkiria) III. Ufa: Bashkirian Branch of the USSR Academy of Sciences, 59-104 (in Russian).

Pshenichniuk, A. Kh. 1972. Otchet o rabotakh arkheologicheskogo otriada IIYAL BF AN SSSR v $1972 \mathrm{~g}$. (Report on the activities of the Archaeological Group of the Institute of History, Language and Literature of the Bashkir Branch of the USSR Academy of Sciences in 1972.). Archive of the Institute of Archaeology of the RAS, Found-1. R-1, Inv. no 4724 (in Russian).

Pshenichniuk, A. Kh. 1973. In Bikbulatov, N. V., Kuzeev, R. G., Mazitov, N. A. (eds.). Arkheologiia $i$ etnografiia Bashkirii (Archaeology and Ethnography of Bashkiria) V. Ufa: Bashkirian Branch of the USSR Academy of Sciences, 162-243 (in Russian).

Pshenichniuk, A. Kh. 1976. In Kuzeev, R. G., Mazhitov, N. A., Pshenichniuk, A. Kh. (eds.). Drevnosti Iuzhnogo Urala (Antiquities of the Southern Urals). Ufa: Bashkirian Branch of the USSR Academy of Sciences, 35-131 (in Russian).

Sal'nikov, K.V. 1962. Otchet o rezul tatkh arkheologicheskoi ekspeditsii za 1962 g. po teme "Epokha zheleza i bronzy v Bashkirii", razdel "Epokha bronzy Yuzhnogo Urala" (Report on the Results of an Archaeological Expedition for 1962 on "The Iron and Bronze Age in Bashkiria", section "The Bronze Age of the Southern Urals"). Archive of the Institute of Archaeology of the RAS, Found-1. R-1, Inv. no 2462 (in Russian).

Savel'ev, N. S. 2011. In Rossiiskaia Arkheologiia (Russian Archaeology) (2), 56-66 (in Russian).

Skripkin, A. S. 1990. Aziatskaia Sarmatiia (problemy khronologii i ee istoricheskii aspekt) (Sarmatia Asiatica: Issues of Chronology and Its Historical Aspect). Saratov: Saratov University (in Russian).

Chizhevsky, A. A. 2008. Arkheologiia evraziiskikh stepei (Archaeology of Eurasian Steppes) 5. Kazan: "Shkola" Publ. (in Russian).

Shokurov, A. P. 1955. Otchet ob arkheologicheskikh razvedke letom 1955 g. v Kushnarenkovskom raione Bashkirskoi ASSR (Report on Archaeological Exploration in the Summer of 1955 in the Kushnarenkovsky District of the Bashkir ASSR). 1. Archive of the Institute of Archaeology of the RAS, Found-1. R-1, Inv. no 1096 (in Russian).

Shokurov, A. P. 1958. Otchet ob arkheologicheskikh rabotakh Tret'ego razvedyvatel'nogo otriada Bashkirskoi arkheologicheskoi ekspeditsii v 1958 g. (Report on the Archaeological Activities of the Third Exploration Group of the Bashkir Archaeological Expedition in 1958) 2. Archive of the Institute of Archaeology of the RAS, Found-1. R-1, Inv. no 4724 (in Russian).

Shutova, N. I. 2001. Dokhristianskie kul'tovye pamiatniki v udmurtskoi religioznoi traditsii:opyt kompleksnogo issledovaniia. (Pre-Christian Religious Monuments in the Udmurt Religious Tradition: the Comprehensive Study Experience) Izhevsk: Udmurt Institute of History, Language and Literature, Ural Branch of the Russian Academy of Sciences (in Russian).

\section{About the Author:}

Ovsyannikov Vladimir V., Candidate of Historical Sciences, Head of the Archaeological Research Department, Institute of History, Language and Literature, Russian Academy of Sciences, Urals Scientific Center. Oktyabrya Av., 721, Ufa, 450054, the Republic of Bashkortostan, Russian Federation; atliural@ yandex.ru 